\title{
Prostate Squamous Cell Carcinoma
}

National Cancer Institute

\section{Source}

National Cancer Institute. Prostate Squamous Cell Carcinoma. NCI Thesaurus. Code C5536.

An invasive prostate carcinoma characterized by the presence of malignant cells with squamous differentiation. There is no evidence of glandular differentiation. 